\title{
Pengaruh Budaya Organisasi Kompensasi dan Motivasi Berprestasi Terhadap Kinerja Dosen Tetap Serta Dampaknya Pada Mutu Pendidikan Universitas Abulyatama Aceh
}

\author{
Lukman T.Ibrahim $^{* 1}$, Mukhlis Yunus ${ }^{2}$, Amri $^{2}$ \\ ${ }^{1}$ Program Studi Manajemen Fakultas Ekonomi Universitas Abulyatama, Aceh Besar, 23372, \\ Indonesia. \\ ${ }^{2}$ Fakultas Ekonomi Universitas Syiah Kuala, Banda Aceh, 23111, Indonesia. \\ *Email korespondensi:_nashroollah@gmail.com ${ }^{1}$
}

Diterima 11 Maret 2018; Disetujui 13 April 2018; Dipublikasi 30 April 2018

\begin{abstract}
This study aims to determine the influence of organizational culture of compensation and achievement motivation on the performance of tenured faculty as well as the impact on the quality of university education Abulyatama Aceh. The study used the SEM analysis model AMOS. After processing the data, obtained by the results of studies showing that the Cultural Organization (X1) Compensation (X2) Achievement Motivation (X3), Performance (Y) and Quality of Education (Z) positively and significantly affect the quality of education at the University Abulyatama Aceh. Thus the hypothesis is entirely acceptable, which means that ( a) the organizational culture in a positive and significant effect on the performance of full-time lecturer at the University Abulyatama Aceh is tested were correct; (b) compensation and significant positive effect on the performance of full-time lecturer at the University Abulyatama Aceh is verified; (c) achievement motivation in a positive and significant effect on the performance of full-time lecturer at the University Abulyatama Aceh is verified; (d) performance and significant positive effect on the quality of education at the University Abulyatama Aceh is verified; (e) the organization's culture, compensation, achievement motivation together in a positive and significant effect on the performance of faculty and the quality of education at the University Abulyatama Aceh
\end{abstract}

Keywords: organizational culture, compensation, motivation and achievement of quality education.

\begin{abstract}
Abstrak: Penelitian ini bertujuan untuk mengetahui pengaruh budaya organisasi kompensasi dan motivasi berprestasi terhadap kinerja dosen tetap serta dampaknya pada mutu pendidikan Universitas Abulyatama Aceh. Penelitian ini memakai model analisis SEM AMOS. Setelah dilakukan pengolahan data, diperoleh hasil penelitian yang menunjukkan bahwa Budaya Organisasi (X1) Kompensasi (X2) Motivasi Berprestasi (X3), Kinerja (Y) dan Mutu Pendidikan (Z) secara positif dan signifikan mempengaruhi mutu pendidikan di Universitas Abulyatama Aceh. Dengan demikian hipotesis dalam penelitian ini seluruhnya dapat diterima yang berarti bahwa (a) budaya organisasi berpengaruh secara positif dan signifikan terhadap kinerja dosen tetap di Universitas Abulyatama Aceh adalah teruji kebenaranya; (b) kompensasi berpengaruh secara positif dan signifikan terhadap kinerja dosen tetap di Universitas Abulyatama Aceh adalah teruji kebenarannya; (c) motivasi berprestasi berpengaruh secara positif dan signifikan terhadap kinerja dosen tetap di Universitas Abulyatama Aceh adalah teruji kebenarannya; (d) kinerja berpengaruh secara positif dan signifikan terhadap mutu pendidikan di Universitas Abulyatama Aceh adalah teruji kebenarannya; (e) budaya organisasi, kompensasi, motivasi berprestasi secara bersama-sama berpengaruh secara positif dan signifikan terhadap kinerja dosen dan terhadap mutu pendidikan di Universitas Abulyatama Aceh.
\end{abstract}

Kata kunci : budaya organisasi, kompensasi, motivasi berprestasi, kinerja dan mutu pendidikan. 
Komitmen terhadap perbaikan mutu untuk sebuah institusi yang ingin tetap bertahan (survive) menjadi keharusan. Tidak terkecuali dengan institusi pendidikan yang bernama perguruan tinggi. Berbicara mutu pendidikan di Indonesia, seperti apakah mutu pendidikan tinggi di Indonesia saat ini, berdasarkan peringkat ARWU (Academic Ranking Of World University) tahun 2013.Perguruan Tinggi di Indonesia belum ada yang masuk dalam rangking seratus besar universitas terkemuka di dunia.

Kemorosotan mutu pendidikan tinggi di Indonesia dapat lihat dari lulusan yang dihasilkan. Banyaknya lulusan perguruan tinggi di Indonesia yang menganggur menjadi indikator bahwa lulusan perguruan tinggi tidak bermutu.Namun upaya yang dilakukan oleh pemerintah untuk terus meningkatkan mutu pendidikan telah menunjukkan perubahan, meskipun belum tercapai sebagaimana yang diharapkan. Badan Pusat Statistik (BPS) mencatat jumlah pengangguran sarjana atau lulusan Universitas pada Februari 2013 mencapai 360.000 orang atau $5,04 \%$ dari total pengangguran yang mencapai 7,2 juta orang.Angka tersebut terus menurun jika dibandingkan dengan Februari 2012 sebesar 6,95\% (BPS, Jakarta, mei 2013).

Djohan dalam Umi Narimawati (2005) menyatakan, bahwa kunci utama untuk meningkatkan mutu pendidikan tinggi adalah lembaga/pimpinan harus meningkatkan mutu dosen, yang akan berakibat dalam meningkatkan kepuasan kerja dan selanjutnya muncul komitmen pada organisasi/lembaga. Peningkatan kualitas dosen dimulai dari sistem perekrutan yang tepat, peningkatan kemampuan dosen, sistem penilaian terhadap kemampuan dan kinerja dosen, serta peningkatan karirnya. Upaya meningkatkan kinerja dosen menjadi hal sangat penting.

Pada setiap lembaga pendidikan tinggi tentunya akan diwarnai oleh budaya organisasi masingmasing, meskipun dasar utama penyelenggaraannya berdasarkan peraturan baik yang ditetapkan oleh pemerintah maupun lembaga yang bersangkutan, perilaku semua orang yang terlibat dalam proses perkuliahan dan juga aktivitas lainnya yang ada. Pabundu (2008) menyatakan, budaya organisasi adalah seperangkat asumsi dasar dan keyakinan yang dianut oleh anggota-anggota organisasi kemudian dikembangkan dan diwariskan guna mengatasi masalah-masalah adaptasi eksternal dan masalah integrasi internal.

Setiap anggota dari suatu organisasi mempunyai kepentingan dan tujuan sendiri ketika ia bergabung pada organisasi tersebut. Untuk menjamin tercapainya keselarasan tujuan, pimpinan organisasi bisa memberikan perhatian dengan memberikan kompensasi, karena kompensasi merupakan faktor penting yang mempengaruhi bagaimana dan mengapa orang-orang memilih untuk bekerja di sebuah organisasi.

Motivasi berprestasi menjadi komponen yang sangat berperan dalam mewujudkan sumberdaya manusia yang berkualitas.Karyawan memiliki motivasi berprestasi yang tinggi akan mempunyai semangat, keinginan dan energi yang besar dalam diri individu untuk bekerja seoptimal mungkin. Jackson dalam Hidayat (2008) menyatakan, bahwa motivasi berprestasi merupakan dorongan yang sangat kuat untuk berusaha dan bekerja keras demi mencapai suatu keberhasilan dan keunggulan. Kurniawan (2005) menyatakan, kinerja merupakan penilaian atas kualitas pengelolaan dan 
kualitas pelaksanaan tugas atau operasi organisasi. Secara umum dapat dijabarkan bahwa mutu pendidikan tinggi sangat ditentukan oleh faktorfaktor yang saling berhubungan (interaksi). Faktor-faktor tersebut antara lain: budaya organisasi, kompensasi, motivasi berprestasi dan kinerja dosen, keempat faktor tersebut memiliki korelasi yang nyata terhadap mutu pendidikan di Universitas Abulyatama Aceh.

Penelitian ini bertujuan untuk membuktikan dan menganalisis pengaruh:

1. Untuk menganalisis pengaruh budaya organisasi terhadap kinerja dosen tetap pada Universitas Abulyatama Aceh.

2. Untuk menganalisis pengaruh kompensasi terhadap kinerja dosen tetap pada Universitas Abulyatama Aceh.

3. Untuk menganalisis pengaruh motivasi berprestasi terhadap kinerja dosen tetap pada Universitas Abulyatama.

4. Untuk menganalisis pengaruh budaya organisasi terhadap mutu pendidikan pada Universitas Abulyatama Aceh.

5. Untuk menganalisis pengaruh kompensasi terhadap mutu pendidikan pada Universitas Abulyatama Aceh.

6. Untuk menganalisis pengaruh motivasi berprestasi terhadap mutu pendidikan pada Universitas Abulyatama Aceh.

7. Untuk menganalisis pengaruh kinerja dosen tetap terhadap mutu pendidikan pada Universitas Abulyatama Aceh.

8. Untuk menganalisis pengaruh budaya organisasi, kompensasi dan motivasi berprestasi terhadap mutu pendidikan melalui kinerja dosen tetap pada Universitas Abulyatama Aceh.

\section{TINJAUAN KEPUSTAKAAN}

\section{Mutu Pendidikan}

Mutu secara umum dapat didefinisikan sebagai gambaran dan karakteristik menyeluruh dari barang atau jasa yang menunjukkan kemampuannya dalam memuaskan kebutuhan sebagaimana yang diharapkan. Oemar Hamalik (2009) menyatakan, mutu pendidikan sering diartikan sebagai karakteristik jasa pendidikan yang sesuai dengan kriteria tertentu untuk memenuhi kepuasan pengguna (user) pendidikan, yakni peserta didik, orang tua, serta pihak-pihak berkepentingan lainnya. Hoy et al, (2006) menyatakan, bahwa mutu pendidikan adalah hasil penilaian terhadap proses pendidikan dengan harapan yang tinggi untuk dicapai dari upaya pengembangan bakat-bakat para pelanggan pendidikan melalui proses pendidikan. Dengan demikian mutu pendidikan merupakan suatu hal yang penting dalam proses pendidikan, oleh karena itu perbaikan proses pendidikan merupakan salah satu upaya untuk mencapai keunggulan dalam penyelenggaraan pendidikan.

\section{Kinerja}

Kinerja memiliki pengertian yang beragam dari berbagai pakar, tetapi tetap memiliki kesamaan secara umum. Robbins (2008) menyatakan, kinerja adalah suatu hasil yang dicapai oleh pegawai dalam pekerjaanya menurut kriteria tertentu yang berlaku untuk suatu pekerjaan.

Rai (2008) menyatakan, kinerja merupakan hasil evaluasi terhadap pekerjaan yang telah dilakukan dibandingkan dengan kriteria yang telah ditetapkan bersama. Berdasarkan pengertian kinerja dari pendapat para ahli tersebut dapat disimpulkan 
bahwa kinerja adalah suatu hasil kerja yang dicapai seseorang didalam menjalankan tugas-tugas yang dibebankan kepadanya dan seberapa banyak mereka dapat memberikan kontribusinya kepada organisasi.

\section{Motivasi Berprestasi}

Motivasi berprestasi merupakan dorongan yang timbul dari dalam diri seseorang untuk melakukan suatu aktivitas kerja dalam rangka mengatasi hambatan, menetapkan solusi berbagai permasalahan yang dihadapi dan menjawab tantangan yang menghadang, guna mencapai prestasi terbaik dengan predikat terpuji kearah pencapaian tujuan.

McClelland dalam Kusumajati (2011) menyatakan bahwa, motivasi berprestasi merupakan usaha untuk mencapai suatu kesuksesan dalam kompetisi dengan suatu ukuran keunggulan. Santrock (2008). Menyatakan, motivasi berprestasi adalah suatu dorongan untuk menyempurnakan sesuatu, untuk mencapai sebuah standar keunggulan dan untuk mencurahkan segala upaya untuk mengungguli.

Secara umum motivasi berprestasi adalah kesungguhan atau daya dorong seseorang untuk berbuat lebih baik dari apa yang pernah dibuat atau diraih sebelumnya maupun yang dibuat atau diraih orang lain, yang dapat diukur melalui berusaha untuk unggul dalam kelompoknya, menyelesaikan tugas dengan baik, rasional dalam meraih keberhasilan, menyukai tantangan, menerima tanggung jawab pribadi untuk sukses, dan menyukai situasi pekerjaan dengan tanggung jawab pribadi, umpan balik, dan resiko tingkat menengah.

\section{Kompensasi}

Salah satu cara manajemen untuk meningkatkan prestasi kerja, memotivasi dan meningkatkan kinerja para karyawan adalah melalui kompensasi. Dessler (2007) menyatakan, kompensasi karyawan adalah semua bentuk pembayaran atau hadiah yang diberikan kepada karyawan dan muncul dari pekerjaan mereka. Bernardin (2007) menyatakan, kompensasi merujuk pada semua bentuk hasil keuangan dan tunjangan nyata yang diterima pegawai sebagai bagian dari hubungan kerja.

Dapat disimpulkan bahwa kompensasi ialah sistem balas jasa yang diterima oleh pegawai dari organisasi atau perusahaan atas usaha yang telah dilakukannya dalam mencapai tujuan organisasi.

\section{Budaya Organisasi}

Dalam kenyataannya tidak ada masyarakat tanpa kebudayaan dan tidak ada kebudayaan diluar sebuah masyarakat. Robbins \& Judge (2008) menyatakan, budaya organisasi merupakan sebuah sistem makna bersama yang dianut oleh para anggota yang membedakan suatu organisasi dari organisasiorganisasi lainnya. Philip Kotler, dalam Mangkunegara (2005) menyatakan, budaya organisasi adalah pengalaman, cerita, keyakinan, dan norma bersama yang menjadi ciri organisasi.

Pada prinsipnya budaya organisasi merupakan nilai, anggapan, asumsi, sikap dan norma perilaku yang telah melembaga kemudian mewujud dalam penampilan, sikap dan tindakan, sehingga menjadi identitas dari organisasi tertentu.

\section{Hipotesis}

Berdasarkan perumusan masalah dan kajian teoritis maupun empirik maka hipotesis dalam penelitian ini adalah: 
$\mathrm{H}_{1}$ : Diduga budaya organisasi berpengaruh secara positif dan signifikan terhadap kinerja dosen tetap pada Universitas Abulyatama Aceh.

$\mathrm{H}_{2}$ : Diduga kompensasi berpengaruh secarapositif dan signifikan terhadap kinerja dose tetap pada Universitas Abulyatama Aceh.

$\mathrm{H}_{3}$ : Diduga motivasi prestasi berpengaruh secara positif dan significant terhadap kinerja dosen tetap pada Universitas Abulyatama Aceh.

$\mathrm{H}_{4}$ : Diduga budaya organisasi berpengaruh secara Positif dan significant terhadap mutu Pendidikan pada Universitas Abulyatama Aceh.

$\mathrm{H}_{5}$ : Diduga kompensasi berpengaruh secara positif dan significant terhadap mutu pendidikan pada Universitas Abulyatama Aceh.

$\mathrm{H}_{6}$ : Diduga motivasi prestasi berpengaruh secara dan significant terhadap mutu pendidikan pada Universitas Abulyatama Aceh.

$\mathrm{H}_{7}$ : Diduga kinerja dosen tetap berpengaruh Secara positif dan significant terhadap mutu Pendidikan pada Universitas Abulyatama Aceh.

$\mathrm{H}_{8}$ : Diduga budaya organisasi kompensasi dan motivasi berprestasi berpengaruh secara posistif dan significant terhadap mutu pendidikan melalui kinerja dosen tetap pada Universitas Abulyatama Aceh.

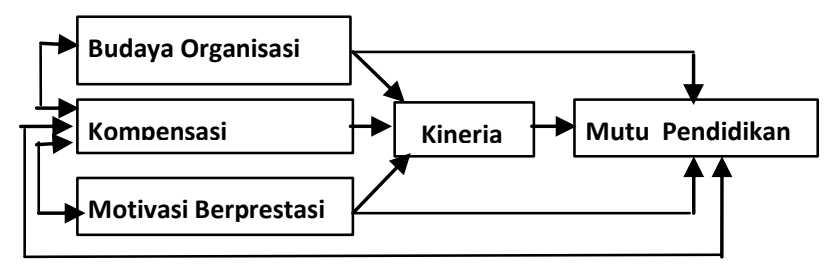

Gambar 1. Kerangka Penelitian

\section{METODE PENELITIAN}

\section{Lokasi dan Objek Penelitian}

Penelitian ini dilaksanakan di Universitas Abulyatama Aceh yang beralamat di Jalan Blang Bintang Lama Km.8,5 Lampoh Keude, Aceh Besar, objek penelitian berkaitan dengan apa dan bagaimana pengaruh budaya organisasi, kompensasi dan motivasi berprestasi terhadap kinerja dosen tetap yayasan serta dampaknya pada mutu pendidikan Universitas Abulyatama Aceh.

\section{Populasi dan Sampel}

Populasi dalam penelitian ini adalah seluruh dosen tetap Yayasan Universitas Abulyatama Aceh yang berjumlah 153 orang. Dua pendekatan umum dalam sampling yang biasanya digunakan dalam penelitian manajemen adalah probability sampling dan non probability sampling Ferdinand, (2006). Penentuan besarnya ukuran sampel penelitian ditentukan menggunakan rumus Slovin (Umar, 2007) sebagai beikut: $\mathrm{n}=\frac{\mathrm{N}}{1+\mathrm{Ne}^{2}} \quad$ dimana $\mathbf{n}=$ ukuran sampel, $\mathbf{N}=$ ukuran populasi, $\mathbf{e}=$ Persentase ketelitian 5\% sehingga besarnya sampel 111 orang.

\section{Sumber Data}

Adapun sumber data dalam penelitian ini diperoleh dari:

1. Data Primer. Data yang diambil langsung dari responden atau dari obyek penelitian melalui 
kuesioner yang diisi oleh dosen tetap yayasan Universitas Abulyatama Aceh.

2. Data Sekunder.Data yang diperoleh secara tidak langsung melalui perantara. Dalam penelitian ini, data sekunder hanya mendukung pengumpulan data awal sebagai output penelitian.

\section{Teknik Pengumpulan Data}

Data primer dikumpulkan dengan menggunakan metode survei dengan wawancara langsung dengan responden, menggunakan daftar pertanyaan, yaitu daftar pertanyaan yang didistribusikan untuk diisi dan dikembalikan atau dapat juga dijawab di bawah pengawasan peneliti.

\section{Operasional Variabel}

Berdasarkan perumusan masalah, uraian teoritis dan hipotesis yang diajukan, maka variabelvariabel dalam penelitian ini adalah sebagai berikut:

\section{Variabel Independen ( X )}

Variabel independen disebut juga dengan variabel bebas yaitu variabel yang mempengaruhi atau yang menjadi sebab perubahannya atau timbulnya variabel dependen (terikat).Variabel independen penelitian yang akan dibahas adalah menyangkut variabel budaya organisasi, kompensasi dan motivasi berprestasi meliputi 7 indikator budaya organisasi yaitu inovasi dan keberanian mengambil resiko, perhatian terhadap detail, berorientasi kepada hasil, berorientasi kepada manusia, berorientasi kepada tim, agresivitas dan stabilitas. Enam indikator kompensasi yaitu; gaji, upah, upah insentif, asuransi, fasilitas kantor dan tujangan. Dan tiga indikator motivasi berprestasi yaitu; mastery of needs, work orientation dan competition.

\section{Variabel Moderator (Y)}

Variabel moderator merupakan variabel yang mempengaruhi (memperkuat atau memperlemah) hubungan antara variabel independen dengan dependen.Variabel moderator dalam penelitian ini adalah kinerja dosen tetap indikatornya yaitu; kualitas, kuantitas, ketepatan waktu, efektivitas, kemandirian dan komitmen kerja.

\section{Variabel Dependent (Z)}

Variabel terikat (dependent) merupakan variabel yang dipengaruhi atau akibat, karena adanya variabel independent.Variabel dependent dalam penelitian ini adalah mutu pendidikan.

\section{Peralatan Analisis Data}

Analisis deskriptif yang digunakan dalam penelitian ini adalah dengan mempergunakan program SPSS dan Analisis data dan interpretasi untuk penelitian yang ditujukan untuk menjawab pertanyaan-pertanyaan penelitian dalam rangka mengungkapkan fenomena sosial tertentu. Analisis data adalah proses penyederhanaan data kedalam bentuk yang lebih mudah dibaca dan diimplementasikan. Metode yang dipilih untuk menganalisis data harus sesuai dengan pola penelitian dan variabel yang akan diteliti. Untuk menganalisis data digunakan The Structural Equation Modeling (SEM) dari paket software statistik AMOS, dalam model dan pengkajian hipotesis. Model persamaan SEM adalah sekumpulan teknik-teknik statistikal yang memungkinkan pengujian sebuah rangkaian hubungan relatif "rumit" secara simultan (Ferdinand, 2006). 


\section{HASIL DAN PEMBAHASAN}

\section{Gambaran Umum Universitas Abulyatama}

Aceh.

Universitas Abulyatama yang berlokasi di Jalan Blang Bintang Lama Km. 8,5 Lampoh Keude Aceh Besar didirikan pada tahun 1984 memiliki gedung dan fasilitas belajar lainnya yang berada dalam satu komplek \pm 40 Ha. Antara lain ruang belajar/perkuliahan, perpustakaan induk, laboratorium anatomi, farmakologi, biologi medik, kimia medik, patologi klinik, fisiologi, fisika medik, parasitologi, histologi, patologi anatomi, biokimia \& mikro biologi, serta laboratorium elektrik, teknik pertanian, perikanan, computer dan kesehatan, lapangan olahraga dan mesjid. Program pendidikan strata satu terdiri dari (1). Fakultas kedokteran, (2). Fakultas teknik, (3). Fakultas pertanian, (4) Fakultas perikanan, (5). Fakultas keguruan dan ilmu pendidikan, (6).Fakultas ekonomi (7). Fakultas hukum, (8). Sekolah tinggi manajemen ilmu computer dan Program pendidikan diploma fakultas kedokteran.

\section{Responden}

Dalam penelitian ini digunakan sampel 111 orang responden yang merupakan dosen tetap Universitas Abulyatama.

\section{Uji Measurement Model}

Gambar berikut menunjukkan hubungan indikator dan unobserved variabel

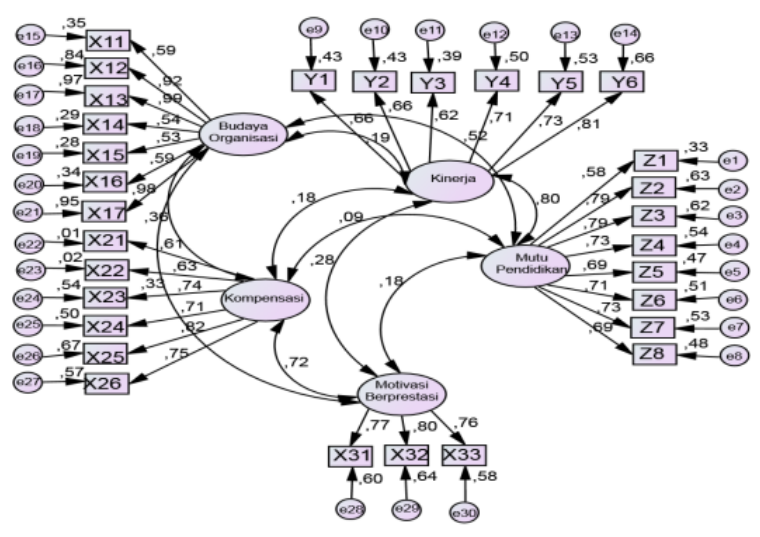

Gambar 2. Measurement Model Dengan Loading Factor

Beberapa tabel berikut menunjukkan hubungan indikator dengan konstruksnya masing-masing. Loading faktor yang digunakan untuk mengukur konstribusi masing-masing indikator bila nilainya diatas 0,5, maka dikatakan indikator itu cukup representative untuk menerangkan unobserved variabel nya. Oleh sebab itu indikator ini harus diikutsertakan pada pemerosesan data selanjutnya.

Tabel 1 Loading Factor Budaya Organisasi

\begin{tabular}{|c|l|c|c|}
\hline Indikator & & Variabel & Loading Factor \\
\hline X11 & $<--$ & Budaya Organisasi & $\mathbf{0 , 5 8 9}$ \\
\hline X12 & $<--$ & Budaya Organisasi & $\mathbf{0 , 9 1 8}$ \\
\hline X13 & $<--$ & Budaya Organisasi & $\mathbf{0 , 9 8 7}$ \\
\hline X14 & $<--$ & Budaya Organisasi & $\mathbf{0 , 5 4 0}$ \\
\hline X15 & $<--$ & Budaya Organisasi & $\mathbf{0 , 5 3 0}$ \\
\hline X16 & $<--$ & Budaya Organisasi & $\mathbf{0 , 5 8 7}$ \\
\hline X17 & $<--$ & \multicolumn{3}{|c|}{ Budaya Organisasi } & $\mathbf{0 . 9 7 7}$ \\
\hline \multicolumn{3}{|c|}{ Sumber : Data Primer, Oktober 2015 (diolah) }
\end{tabular}

Loading factor indikator dari unobserved variabel budaya organisasi yang mempunyai skor tertinggi adalah X13 yaitu "lembaga pendidikan tempat saya mengajar mendorong saya penekanannya pada hasil proses perkuliahan, tapi juga proses usaha untuk mencapai hasil yang optimal" yaitu 0,987 atau indikator tersebut memberikan kontribusi sebesar 98,7\% terhadap variabel budaya organisasi, dan nilai yang terendah berada pada indikator X15 dengan pernyataan "senantiasa menjaga hubungan baik antara sesama 
staf pengajar sehingga jadwal perkuliahan tetap berjalan apabila salah satu staf pengajar berhalangan" dengan nilai sebesar 0,530 atau indikator tersebut hanya memberikan kontribusi sebesar 53\% terhadap variabel budaya organisasi.

Tabel 2 Loading Factor Variabel Kompensasi

\begin{tabular}{|c|c|r|r|}
\hline Indikator & & Variabel & Loading Factor \\
\hline X21 & $<---$ & Kompensasi & $\mathbf{0 , 6 1 1}$ \\
\hline X22 & $<---$ & Kompensasi & $\mathbf{0 , 6 2 7}$ \\
\hline X23 & $<---$ & Kompensasi & $\mathbf{0 , 7 3 5}$ \\
\hline X24 & $<---$ & Kompensasi & $\mathbf{0 , 7 0 8}$ \\
\hline X25 & $<---$ & Kompensasi & $\mathbf{0 , 8 1 6}$ \\
\hline X26 & $<---$ & Kompensasi & $\mathbf{0 , 7 5 2}$ \\
\hline
\end{tabular}

Sumber : Data Primer, Oktober 2015 (diolah)

Loading factor indikator dari unobserved variabel kompensasi yang mempunyai skor tertinggi adalah indikator X25 yaitu "faslitas-fasilitas (ruang kantor, tempat ibadah, tempat parkir, dan fasilitas yang lainnya) yang diberikan oleh lembaga membuat staf pengajar merasa nyaman dalam mengajar" yaitu 0,816 atau indikator tersebut memberikan kontribusi sebesar $81,6 \%$ terhadap variabel kompensasi. Sementara nilai terendah terletak pada indikator X21 dengan pernyataan "gaji atau upah yang saya terima dari lembaga pendidikan tempat saya mengajar sudah sesuai dengan jenjang pendidikan/pangkat" dengan nilai sebesar 0,611 atau indikator tersebut hanya memberikan kontribusi sebesar $61,1 \%$ terhadap variabel kompensasi.

Tabel 3 Loading Faktor Variabel Motivasi Berprestasi

\begin{tabular}{|c|c|c|c|}
\hline Indikator & & Variabel & $\begin{array}{l}\text { Loading } \\
\text { Factor }\end{array}$ \\
\hline X31 & $<---$ & Motivasi Berprestasi & $\mathbf{0 , 7 7 3}$ \\
\hline X32 & $<---$ & Motivasi Berprestasi & $\mathbf{0 , 8 0 1}$ \\
\hline X33 & $<---$ & Motivasi Berprestasi & $\mathbf{0 , 7 6 1}$ \\
\hline
\end{tabular}

Sumber : Data Primer, Oktober 2015 (diolah)

Loading factor indikator dari unobserved variabel motivasi berprestasi yang mempunyai skor tertinggi adalah indikator X32 dengan pernyataan "saya merasa bangga dan puas jika telah bekerja keras untuk menyelesaikan tugas mengajar pada lembaga pendidikan tempat saya mengajar" yaitu 0,801 , yang berarti bahwa pernyataan tersebut memberi kontribusi sebesar $80,1 \%$ terhadap variabel motivasi prestasi. Sementara nilai terendah terdapat pada indikator X33 dengan pernyataan "saya berusaha bersaing dengan staf pengajar lainnya pada lembaga pendidikan tempat saya mengajar dengan wajar demi meningkatkan karir" yatiu memberi kontribusi sebesar 0,761 atau memberikan kontribusi sebesar $76,1 \%$ terhadap variabel motivasi prestasi.

Tabel 4 Loading Factor Variabel Kinerja

\begin{tabular}{|c|c|c|c|}
\hline Indikator & & Variabel & Loading Factor \\
\hline Y1 & $<---$ & Kinerja & $\mathbf{0 , 6 5 5}$ \\
\hline Y2 & $<---$ & Kinerja & $\mathbf{0 , 6 5 5}$ \\
\hline Y3 & $<---$ & Kinerja & $\mathbf{0 , 6 2 3}$ \\
\hline Y4 & $<---$ & Kinerja & $\mathbf{0 , 7 0 5}$ \\
\hline Y5 & $<---$ & Kinerja & $\mathbf{0 , 7 2 6}$ \\
\hline Y6 & $<---$ & Kinerja & $\mathbf{0 , 8 1 4}$ \\
\hline
\end{tabular}

Sumber : Data Primer, Oktober 2015 (diolah)

Loading factor indikator dari unobserved variabel kinerja yang mempunyai skor tertinggi adalah indikator Y6 terletak pada pernyataan "saya mempunyai komitmen untuk melaksanakan tugas mengajar dengan disiplin sehingga menghasilkan kinerja yang baik" yaitu 0,814 , yang berarti bahwa pernyataan tersebut memberikan kontribusi sebesar $81,4 \%$ terhadap variabel kinerja. Sementara nilai terendah terdapat pada indikator Y3 dengan pernyataan "saya berusaha untuk tidak pernah menunda pelaksanaan jadwal mengajar dan sesuai dengan jadwal yang telah ditetapkan oleh lembaga" memberikan kontribusi paling rendah yaitu sebesar 0,623 atau memberikan kontribusi sebesar 62,3\% terhadap variabel kinerja.

Tabel 5 Loading Factor Variabel Mutu Pendidikan

\begin{tabular}{|c|c|c|c|}
\hline Indikator & & Variabel & $\begin{array}{c}\text { Loading } \\
\text { Factor }\end{array}$ \\
\hline $\mathbf{Z 1}$ & $<---$ & Mutu Pendidikan & $\mathbf{0 , 5 7 5}$ \\
\hline $\mathbf{Z 2}$ & $<---$ & Mutu Pendidikan & $\mathbf{0 , 7 9 1}$ \\
\hline
\end{tabular}




\begin{tabular}{|c|c|l|c|}
\hline Z3 & $<---$ & Mutu Pendidikan & $\mathbf{0 , 7 8 9}$ \\
\hline Z4 & $<---$ & Mutu Pendidikan & $\mathbf{0 , 7 3 2}$ \\
\hline Z5 & $<---$ & Mutu Pendidikan & $\mathbf{0 , 6 8 8}$ \\
\hline Z6 & $<---$ & Mutu Pendidikan & $\mathbf{0 , 7 1 2}$ \\
\hline Z7 & $<---$ & Mutu Pendidikan & $\mathbf{0 , 7 2 9}$ \\
\hline Z8 & $<---$ & Mutu Pendidikan & $\mathbf{0 , 6 9 5}$ \\
\hline
\end{tabular}

Sumber : Data Primer, Oktober 2015 (diolah)

Loading factor indikator dari unobserved variabel mutu pendidikan yang mempunyai skor tertinggi adalah indikator Z2 d dengan materi yang diberikan kepada mahasiswa", yaitu 0,791, yang berarti bahwa indikator tersebut memberi kontribusi sebesar 79,1 persen terhadap variabel mutu pendidikan. Sementara nilai terendah terdapat pada indikator Z1 dengan pernyataan "mutu pendidikan salah satunya sangat ditentukan oleh kualitas dan komitmen seorang staf pengajar" memberikan kontribusi paling rendah yaitu sebesar 57,5 persen terhadap variabel mutu pendidikan.

\section{Analisis Structural Equation Modeling}

Analisis selanjutnya adalah analisis Structural Equation Model (SEM) secara Full Model yang dimaksudkan untuk menguji model dan hipotesis yang dikembangkan dalam penelitian ini. Pengujian model dalam Structural Equation Model dilakukan dengan dua pengujian, yaitu uji kesesuaian model dan uji signifikansi kausalitas melalui uji koefisien regresi. Hasil pengolahan data untuk analisis SEM terlihat pada Gambar 3 di bawah ini

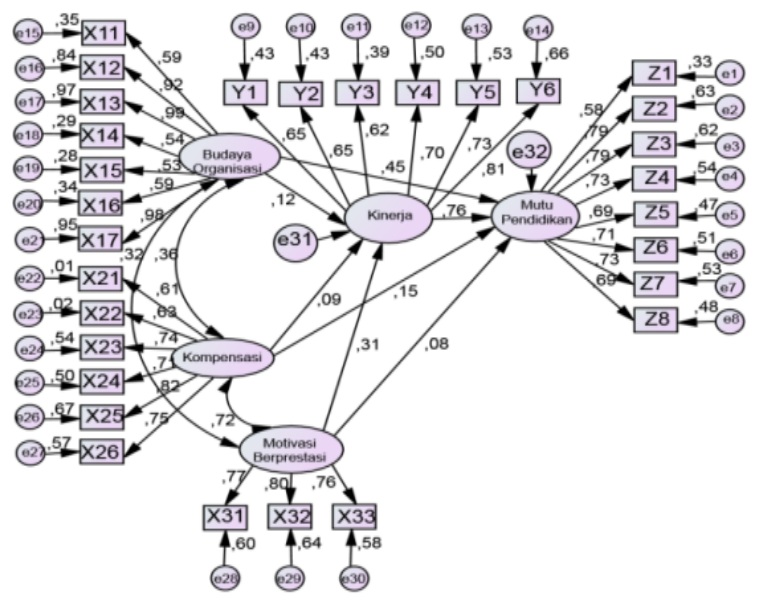

Gambar 3 Structural Equation Modeling

\section{Pengujian hipotesis}

Hipotesis:1. Pengaruh budaya organisasi terhadap kinerja.

Parameter estimasi untuk pengujian pengaruh budaya organisasi terhadap kinerja menunjukkan nilai CR sebesar 2,186 dan dengan probabilitas sebesar 0,030, dimana nilai $\mathrm{CR}>1,96$ dan probabilitas $<0,05$. Dimana terdapat pengaruh positif dan signifikan antara variabel budaya organisasi terhadap variabel kinerja.

\section{Hipotesis:2. Pengaruh kompensasi terhadap} kinerja.

Parameter estimasi untuk pengujian pengaruh Kompensasi terhadap kinerja menunjukkan nilai CR sebesar 2,507 dan dengan probabilitas sebesar 0,05 , dimana nilai $\mathrm{CR}>1,96$ dan probabilitas < 0,05. Dimana terdapat pengaruh positif dan signifikan antara variabel kompensasi terhadap variabel kinerja.

Hipotesis:3. Pengaruh motivasi berprestasi Terhadap kinerja.

Parameter estimasi untuk pengujian pengaruh 
motivasi prestasi terhadap kinerja. menunjukkan nilai CR sebesar 2,294 dan dengan probabilitas sebesar 0,027, dimana nilai $\mathrm{CR}>1,96$ dan probabilitas $<0,05$. Dimana terdapat pengaruh positif dan signifikan antara variabel motivasi prestasi terhadap variabel kinerja .

\section{Hipotesis:4.Pengaruh budaya organisasi} terhadapmutu pendidikan.

Parameter estimasi untuk pengujian budaya organisasi terhadap mutu pendidikan menunjukkan nilai CR sebesar 4,676 dan dengan probabilitas sebesar 0,000 , dimana nilai $\mathrm{CR}>1,96$ dan probabilitas $<$ 0,05.Dimana terdapat pengaruh positif dan signifikan antara variabel budaya organisasi terhadap variabel mutu pendidikan.

\section{Hipotesis:5. Pengaruh kompensasi} terhadap mutu pendidikan.

Parameter estimasi untuk pengujian pengaruh kompensasi terhadap mutu pendidikan menunjukkan nilai CR sebesar 2,310 dan dengan probabilitas sebesar 0,019 , dimana nilai $\mathrm{CR}>1,96$ dan probabilitas $<0,05$.Dengan demikian terdapat pengaruh positif dan signifikan antara variabel kompensasi terhadap variabel mutu pendidikan.

\section{Hipotesis:6. Pengaruh motivasi berprestasi terhadap terhadap mutu pendidikan.}

Parameter estimasi untuk pengujian pengaruh motivasi prestasi terhadap mutu pendidikan menunjukkan nilai $\mathrm{CR}$ sebesar 2,538 dan dengan probabilitas sebesar 0,013, dimana nilai $\mathrm{CR}>1,96$ dan probabilitas $<$ 0,05.Dimana terdapat pengaruh positif dan signifikan antara variabel motivasi prestasi terhadap variabel mutu pendidikan.
Hipotesis:7. Pengaruh

Kinerja

Terhadap Mutu Pendidikan.

Parameter estimasi untuk pengujian pengaruh kinerja dosen tetap terhadap mutu pendidikan menunjukkan nilai CR sebesar 5,104 dan dengan probabilitas sebesar 0,000 dimana nilai $\mathrm{CR}>1,96$ dan probabilitas $<0,05$. Dengan demikian terdapat pengaruh positif dan signifikan antara variabel kinerja terhadap mutu pendidikan.

\section{Tabel 6 Kesimpulan Hipotesis 1-7}

\begin{tabular}{|c|c|c|c|c|}
\hline No & Hipotesis & $\mathbf{C R}$ & $\mathbf{P}$ & Keterangan \\
\hline \multirow[t]{2}{*}{1} & Hipotesis1: & & & $\mathrm{H}_{1}$ \\
\hline & $\begin{array}{l}\text { Pengaruh budaya } \\
\text { organisasi terhadap } \\
\text { kinerja }\end{array}$ & 2,186 & 0,030 & Diterima \\
\hline \multirow[t]{2}{*}{2} & Hipotesis $2:$ & & & $\mathrm{H}_{2}$ \\
\hline & $\begin{array}{l}\text { Pengaruhkompensasi } \\
\text { terhadap kinerja }\end{array}$ & 2,507 & 0,015 & Diterima \\
\hline \multirow[t]{2}{*}{3} & Hipotesis 3 : & & & $\mathrm{H}_{3}$ \\
\hline & $\begin{array}{l}\text { Pengaruh } \\
\text { motivasiberprestasi } \\
\text { terhadap kinerja }\end{array}$ & 2,294 & 0,027 & Diterima \\
\hline \multirow[t]{2}{*}{4} & Hipotesis 4: & & & $\mathrm{H}_{4}$ \\
\hline & $\begin{array}{l}\text { Pengaruh budaya } \\
\text { organisasi terhadap } \\
\text { mutu pendidikan }\end{array}$ & 4,676 & $* * * *$ & Diterima \\
\hline \multirow[t]{2}{*}{5} & Hipotesis 5 : & & & $\mathrm{H}_{5}$ \\
\hline & $\begin{array}{l}\text { Pengaruh kompensasi } \\
\text { terhadap mutu } \\
\text { pendidika }\end{array}$ & 2,310 & 0,019 & Diterima \\
\hline \multirow[t]{2}{*}{6} & Hipotesis 6 : & & & $\mathrm{H}_{6}$ \\
\hline & $\begin{array}{l}\text { Pengaruh motivasi } \\
\text { prestasi terhadap mutu } \\
\text { pendidikan }\end{array}$ & 2,538 & 0,013 & Diterima \\
\hline \multirow[t]{2}{*}{7} & Hipotesis 7 : & & & $\mathrm{H}_{7}$ \\
\hline & $\begin{array}{l}\text { Pengaruh kinerja } \\
\text { terhadap mutu } \\
\text { pendidikan }\end{array}$ & 5,104 & $* * * *$ & Diterima \\
\hline
\end{tabular}

Hipotesis:8. Pengaruh Budaya Organisasi Kompensasi dan Motivasi Berprestasi Terhadap mutu Pendidikan melalui Kinerja.

Efek langsung (direct effect) tidak lain adalah koefisien dari semua garis koefisien dengan anak panah satu ujung. Efek tidak langsung (indirect effect) adalah efek yang muncul melalui sebuah variabel antara. Efek total adalah efek dari berbagai gai hubungan (Ferdinand, 2006). 


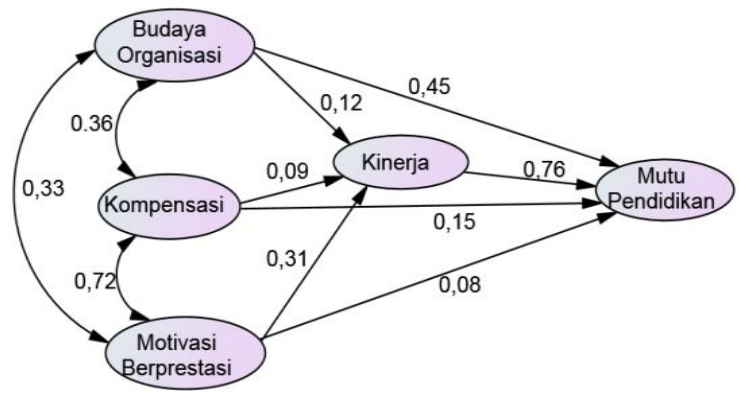

Gambar 4 Pengaruh Antar Variabel Dalam Diagram Alur

Berdasarkan hasil koefisien dari structural equation modeling menunjukkan pengaruh langsung, tidak langsung, dan pengaruh total dari variabel-variabel yang di teliti.

Tabel 7 Pengujian Pengaruh Variabel Intervening

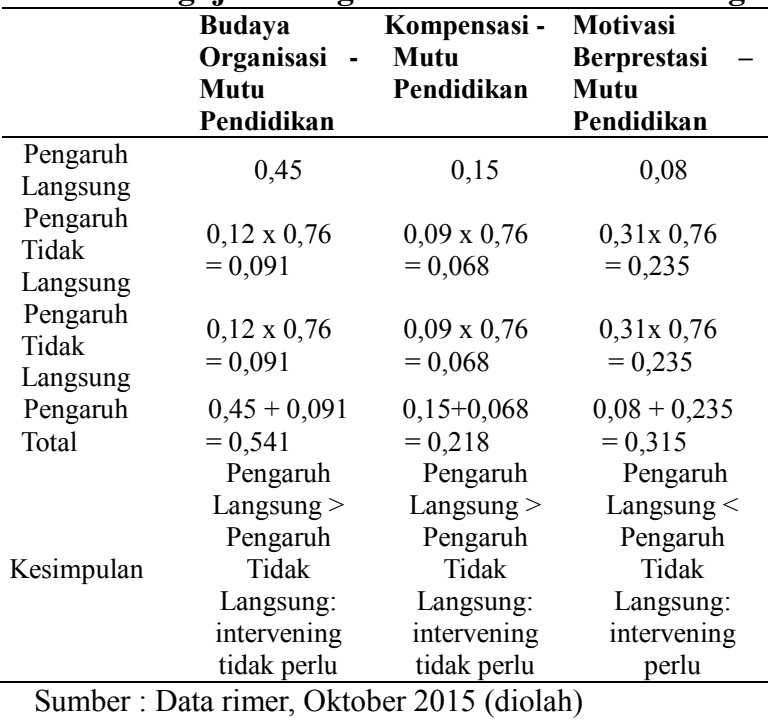

Dari informasi yang disajikan dalam tabel 7 , diketahui bahwa pengaruh budaya organisasi dan kompensasi terhadap mutu pendidikan masingmasing memiliki pengaruh langsung yang lebih besar jika dibandingkan dengan pengaruh tidak langsung, artinya kinerja dosen tetap tidak memiliki peran yang penting dalam memediasi pengaruh budaya organisasi dan kompensasi terhadap mutu pendidikan. Sedangkan motivasi berprestasi memiliki pengaruh langsung lebih kecil jika dibandingkan dengan pengaruh tidak langsung artinya kinerja dosen tetap memiliki peran penting dalam memediasi pengaruh motivasi berprestasi terhadap mutu pendidikan pada Universitas Abulyatama Aceh.

\section{Implikasi Manjerial}

Berdasarkan hasil penelitian diperoleh informasi pada pengaruh kompensasi terhadap kinerja pegawai, maka disarankan kepada Universitas Abulyatama Aceh untuk terus memberikan motivasi untuk berprestasi terhadap dosen-dosen pada lembaga tersebut, hal ini perlu dilakukan karena dari hasil penelitian menunjukkan motivasi prestasi memberikan pengaruh paling tinggi terhadap perubahan kinerja yaitu sebesar 31 persen dan kinerja memberikan pengaruh 76 persen terhadap perbaikan mutu pendidikan di Universitas Abulyatama Aceh.

Untuk peningkatan mutu pendidikan pada Universitas Abulyatama Aceh diharapkan kepada pengelola lembaga pendidikan tersebut untuk terus memperbaiki budaya organisasi.Hasil penelitian menunjukkan bahwa budaya organisasi memberikan pengaruh lansung yang tinggi yaitu sebesar $45 \%$ terhadap perbaikan mutu pendidikan pada Universitas Abulyatama Aceh. Dan juga berusaha untuk meningkatkan kinerja para dosen dengan memberikan motivasi untuk berprestasi, memperbaiki budaya organisasi dan memberikan kompensasi yang memadai, ini perlu dilakukan karena hasil penelitian menunjukkan bahwa kinerja para dosen sangat menentukan mutu pendidikan, dimana 76 persen mutu pendidikan pada Universitas Abulyatama Aceh dipengaruhi oleh kinerja para dosen. 


\section{KESIMPULAN DAN SARAN}

\section{Kesimpulan}

Setelah disajikan hasil penelitian dan pembahasan serta analisa data pada bab-bab sebelumnya maka dapat ditarik beberapa kesimpulan dan saran dalam penelitian ini antara lain:

1. Budaya organisasi berpengaruh secara positif dan signifikan terhadap kinerja dosen tetap pada Universitas Abulyatama Aceh.

2. Kompensasi berpengaruh secara positif dan signifikan terhadap kinerja dosen tetap pada Universitas Abulyatama Aceh.

3. Motivasi berprestasi berpengaruh secara positif dan signifikan terhadap kinerja dosen tetap pada Universitas Abulyatama Aceh.

4. Budaya organisasi berpengaruh secara positif dan signifikan terhadap mutu pendidikan pada Universitas Abulyatama Aceh.

5. Kompensasi berpengaruh secara positif dan signifikan terhadap mutu pendidikan pada Universitas Abulyatama Aceh.

6. Motivasi berprestasi berpengaruh secara positif dan signifikan terhadap terhada mutu pendidikan pada Universitas Abulyatama Aceh.

7. Kinerja berpengaruh secara positif dan signifikan terhadap mutu pendidikan pada Universitas Abulyatama Aceh.

8. Budaya organisasi dan kompensasi terhadap mutu pendidikan memiliki pengaruh langsung lebih besar jika dibandingkan dengan pengaruh tidak langsung, artinya kinerja dosen tetap tidak memiliki peran yang penting dalam memediasi pengaruh budaya organisasi dan kompensasi terhadap mutu pendidikan. Sedangkan motivasi berprestasi memiliki pengaruh langsung lebih kecil jika dibandingkan dengan pengaruh tidak langsung artinya kinerja dosen tetap memiliki peran penting dalam memediasi pengaruh motivasi berprestasi terhadap mutu pendidikan pada Universitas Abulyatama Aceh.

\section{Saran}

1. Agar terus memberikan motivasi untuk berprestasi terhadap dosen, hal ini perlu dilakukan karena motivasi prestasi memberikan pengaruh paling tinggi terhadap perubahan kinerja karena kinerja sangat menentukan terhadap perbaikan mutu pendidikan di Universitas Abulyatama Aceh.

2. Agar memperbaiki budaya organisasi ke arah yang lebih baik, karena budaya organisasi sangat berpengaruh terhadap baik buruknya mutu pendidikan pada Universitas Abulyatama Aceh.

3. Perlu terus meningkatkan kinerja para dosen pengajar dengan memberikan motivasi untuk berprestasi, memperbaiki budaya organisasi dan memberikan kompensasi yang memadai, hal ini perlu dilakukan karena kinerja para dosen sangat menentukan mutu pendidikan pada Universitas Abulyatama Aceh.

\section{DAFTAR PUSTAKA}

Umi Narimawati. (2005). Pengaruh Person Jobfit, Kepuasan \& Komitmen Terhadap Keinginan Pindah Dan kinerja Dosen PTS. Kopertis Wilayah IV Jabar Dan Banten. Disertasi. Unpad. Bandung.

Moh. Pabundu Tika MM (2008). Budaya Organisasi dan Peningkatan Kinerja Perusahaan. Bumi Aksara.

Hidayat, S. (2008). Hubungan minat terhadap 
profesi guru dan motivasi berprestasi dengan keterampilan mengajar. Jurnal Pendidikan dan Kebudayaan. 140.

Kurniawan. (2005). Dasar-dasar Pelayanan Publik. Edisi Kedua. Jilid I Salemba Empat. Jakarta: PT Prenhallindo

P.Robbins, Stephen. (2008). Organizational Behaviour, Tenth Edition. (Prilaku Organisasi Edisi Ke Sepuluh). Alih Bahasa Drs.Benyamin Molan. Jakarta: Salemba Empat.

I Gusti Agung Rai. (2008). Audit Kinerja Pada Sektor Publik: Konsep, Praktik, dan Studi Kasus. Jakarta: Salemba Empat.

John W.Santrock (2008). Psikologi Pendidikan. Jakarta: Predana Media Group.

Dessler, Gary. (2007). Manajemen Sumber Daya Manusia. Edisi Kesepuluh. Jilid2. Jakarta: PT. Indeks.

Bernardin, H. John. (2007). Human Resources Management: An Experiential Approach. New York: Mc GrawHill/Irwin.

Robbins, Stephen P. dan Timothy A. Judge. (2008). Perilaku Organisasi. Edisi ke-12. Jakarta: Salemba Empat.

Mangkunegara, A.A Anwar Prabu. (2005). Perilaku dan Budaya Organisasi. Bandung: Refika Aditama.

Hoy, Charles et al. (2006). Improving Quality in Education. London: Falmer Press.

Oemar Hamalik (2009). Kurikulum dan Pembelajaran. Jakarta: Bumi Aksara.

Santrock, J.W. (2008). Educational psychology. (2nd ed.). Jakarta: Kencana.
Safrijal. (2013). Pengaruh Komp Organisasi Dan Motivasi Kerja Terhadap Kinerja Dosen. (Studi Kasus Di Stikes Cut Nyak Dhien Langsa). Jurnal Educandu S3 Unimed, 2(2).

Wibowo. (2010). Budaya Organisasi (Sebuah Kebutuhan Untuk Meningkatkan Kinerja Jangka Panjang). Jakarta: PT. Raja Grafindo Persada.

Tika, Pabundu. (2008). Budaya Organisasi dan Peningkatan Kinerja Perusahaan. Jakarta: Bumi Aksara.

- How to cite this paper:

T.Ibrahim, L., Yunus, M., \& Amri, A. (2018). Pengaruh Budaya Organisasi Kompensasi dan Motivasi Berprestasi Terhadap Kinerja Dosen Tetap Serta Dampaknya Pada Mutu Pendidikan Universitas Abulyatama Aceh. Jurnal Humaniora, 2(1), 61-73. 